\title{
Diagnostic Bioterrorism Response Strategies
}

\author{
Rickard Knutsson \\ National Veterinary Institute (SVA), \\ Sweden
}

\section{Introduction}

Various biological agents such as bacteria, parasites, viruses and toxins may be deliberately released and spread through feed, food, water and air to cause harm and panic (Rotz et al., 2004). These biological agents can infect humans and animals but also crops (Gullino, 2008). Bioterrorism is probably the most inter-sectoral and international challenges among Chemical, Biological, Radiological, and Nuclear (CBRN) threats. To improve the interactions between these sectors there are some key issues involving R\&D, training, event exercises, early warning and effective communication strategies that need to be addressed to rapidly share event information related to detection and identification. In this perspective, diagnostic capabilities are critical components to enhance the preparedness against bioterrorism (Morse, 2004). Covert and overt incidents will lead to various alarm chains. In a covert incident, which is characterized by an unannounced release, the early response and detection will be driven by public health organizations. However, an overt incident is characterized by the fact that the perpetrator announces responsibility and the response will therefore be driven by law enforcement. A diagnostic response strategy must be able to address both types of incidents. This requires a multidisciplinary network composed of diagnostic capabilities both in law enforcement agencies and public health organizations such as environmental, agricultural, veterinary, and food. As a result, laboratory response networks have been developed in different countries. The US Laboratory Response Network (LRN) was established in 1999. Its formation was based on a presidential order (Decision Directive 39) in which the Centers for Disease Control and Prevention (CDC), Association of Public Health Laboratories (APHL), Federal Bureau of Investigation (FBI), and United States Army Medical Research Institute of Infectious Diseases (USAMRIID) was involved (Morse, 2003). The objective of the US LRN is to ensure an effective laboratory response to bioterrorism by improving the law enforcement and public health laboratory infrastructure. The US LRN links local, state and national public health laboratories, as well as agriculture, veterinary, military, water- and food testing laboratories. In addition, the LRN links also to international laboratories in Canada, Australia, Japan, United Kingdom and Germany. Several other countries have developed similar laboratory networks such as Canada (CRTI, 2007), Australia (Editorial, 2004) and South Korea (Hwang, 2008). A Swedish LRN was established in 2009 with the aim of facilitating collaboration between law enforcement, first responders and public health agencies. The Swedish Forum for Biopreparedness Diagnostics (FBD) was established in 2007. FBD is a national laboratory multiagency cooperation, consisting of partners from the National Food Administration (SLV), the Swedish Defense Research Agency (FOI), the National Veterinary Institute (SVA) and the Swedish Institute 
for Communicable Disease Control (SMI). The aim of FBD is to strengthen the diagnostic capacity in Sweden regarding dangerous pathogens. The various laboratory networks that have been established in different countries have more or less the same objectives: rapid detection, identification and characterization of pathogens, targeted surveillance programs, strengthen laboratory response capacities and capabilities, and recovery. This includes; harmonization of diagnostic methods, increasing diagnostic capacity, training and exercises, interactions with other networks, and coordination of diagnostic emergency response. For these reasons, a broad diagnostic portfolio is needed in order to respond to covert and overt bioterrorism incidents. Diagnostic collaboration and networks are essential for an efficient response to a bioterrorism attack. Diagnostic response strategies must consider the abilities of the network in handling of the following: laboratories expertise, index case, decision making, tracing and tracking, and crime scene investigations.

\section{Strategic planning}

To obtain international multisectoral cooperation, in terms of bioterrorism prevention, policy makers have an important function. Policy makers at the local, regional, national and international levels must work in the same direction. However, this is not always realistic and as a result strategic planning is crucial, and the use of planning scenarios (DHS, 2005) can enhance strategic planning (Davis et al., 2007). Interagency collaborative efforts are one of the most critical factors to ensure an efficient bioterrorism preparedness and response plan. Several intergovernmental organizations such as INTERPOL (INTERPOL, 2010), World Health Organization (WHO), Food and Agricultural Organization (FAO) and World Organization for Animal Health (OIE) have ongoing programs and activities to counter the threat of attacks on humans, animals and plants (Pearson, 2006). The Biological and Toxin Weapon Convention (BTWC) prohibits the deliberate release of agents to attack plants, animals and humans (UN, 1972). However, effective prevention and countermeasures for deliberate attacks need to be developed in harmony with measures to control either natural or accidental outbreaks of disease.

A lot of strategic planning is taking place at the national level. For example, reports by the US Congressional Research Service identifies strategic planning as one of four critical areas of bioterrorism preparedness and that agency implementation will be a key component to translate strategic goals into effective programs and polices (Gottron, 2011). The European Union has also developed strategic plans on how to counter bioterrorism and CBRN attacks that are outlined in the EU CBRN Action Plan (EC, 2009). The Action Plan will be implemented in the period 2010 to 2014. Some examples of other countries focusing on strategic planning for bioterrorism are Canada (CRTI, 2007), South Korea (Hwang, 2008). A lot of progress has been made in strengthening local, regional/state, national and international capacities to detect and respond to bioterrorism since letters containing spores of Bacillus anthracis were sent via the US mail in 2001 (Rotz et al., 2004) (Smith, 2004). The anthrax letters caused the CDC to revise its strategic plan for bioterrorism preparedness and response (Koplan, 2001), which is focused on the following six focus areas:

1. Preparedness planning and readiness assessment (including the National Pharmaceutical Stockpile);

2. Detection, surveillance and epidemiology capacity;

3. Laboratory capacity including diagnosis and characterization of biological agents; 
4. Response and health alert network/communications and information technology;

5. Communicating Health Risks and Health Information Dissemination; and

6. Education and training (Kun et al., 2002).

The European political leadership has made efforts to improve a coordinated EU response to the bioterrorism incidents. (Sundelius et al., 2004) (Tegnell et al., 2003). The efforts have improved strategic, tactical, and operational aspects of preparedness planning and response (Brandeau et al., 2009). The strategic planning efforts have formed the basis for multisectoral R\&D activities within the field of bioterrorism diagnostics and have improved the laboratory response networks and interagency cooperation.

\section{Laboratory infrastructure and communication}

Interagency and multi-sectoral laboratory cooperation requires a well developed infrastructure in terms of (i) communication and IT-systems, (ii) facilities, (iii) instruments/equipments and (iv) staff. A solid interagency cooperation of the public health laboratories, veterinary, agriculture, military, and water- and food-testing laboratories infrastructure must be based on strategic plans. These plans must facilitate building integrated response architectures and the promotion of coordination. Various tools, such as discrete event simulation modeling (Hupert et al., 2002) and information infrastructure tools (Kun et al., 2002) are useful in developing the interagency cooperation for laboratory bioterrorism preparedness.

Communication and IT-systems. The laboratory infrastructure must include services to inform and communicate accurate diagnostic data at different levels (Zarcone et al., 2010). A key element for bioterrorism preparedness is information exchange and diseases outbreaks reporting (Horton et al., 2002). Surveillance systems are crucial for early warning of biothreat agents and a coordinated information infrastructure between surveillance and laboratory activities is needed. It has been found that there is a need for coordination between syndromic and laboratory based surveillance (Sintchenko et al., 2009). The diagnostic response strategies must simultaneously fit both the epidemiological and criminal investigations and ongoing activities to improve capabilities to share electronic laboratory diagnostic data (Zarcone et al., 2010). Rational communication procedures are a key mechanism to effective bioterrorism preparedness (Pien et al., 2006). Appropriate and secure communication tools are especially important in the alarm chain allowing police and first responders to contact public and animal health official in terms of covert and overt bioterrorism incident (Holmdahl et al,. 2011). In addition, it is important to facilitate communication between clinicians, sentinel laboratories and US LRN reference laboratories. A failure to communicate information may lead to delayed detection and a greater pressure to handle the incident (Pien et al., 2006). An important infrastructure feature is data handling and electronic information sharing. The US LRN includes approximately 1200 users which require a central point of contact (Morse, 2003). To securely share standard laboratory results between laboratories, LRN Results Messenger (LRN RM) has been established (CDC, 2007). The need for sharing data was clearly identified during the anthrax letter incident in 2001. Approximately 125,000 samples and more than 1 million tests were reported during the event (CDC, 2007). The lack of efficient data sharing tools made it difficult for the laboratories to share data. Laboratory results are critical during an outbreak and they facilitate the decision making. Therefore, to support early detection and response the laboratory should share data (CDC, 2007). The LRN RM has been installed in more than 
150 LRN laboratories including public health, military, federal, food, veterinary and international labs (CDC, 2007). It allows storage and sharing of tests results for biological LRN assays. In addition, the data management supports electronic reporting of proficiency testing results and the ability of laboratories to review their test results and their performance.

Facilities and laboratories. To respond to human, animal and plant biothreat agents a number of laboratory facilities are needed; e.g. clinical laboratories, animal laboratories, plant laboratories, environmental laboratories, military laboratories and forensic laboratories. Most biothreat agents, which are also select agents (CDC) (APHIS), require various biosafety levels due to their pathogenic characteristics. According to work biosafety regulations agents such as Variola major (smallpox) and viral hemorrhagic fevers (Ebola, Marburg, etc) requires work at Biosafety Level 4 (BSL-4). Other agents such as Bacillus anthracis, Fransicella tularensis, and Yersinia pestis require BSL-3 laboratories. Foot and Mouth Disease virus (FMD), which is an animal pathogen, also requires a BSL-3 laboratory. In total, there are various laboratory levels such as BSL-2, BSL-3, BSL-4 and BSL-2 and BSL-3 animal facilities. All of these facilities have various design features and each facility has to fulfill different functional and operational goals.

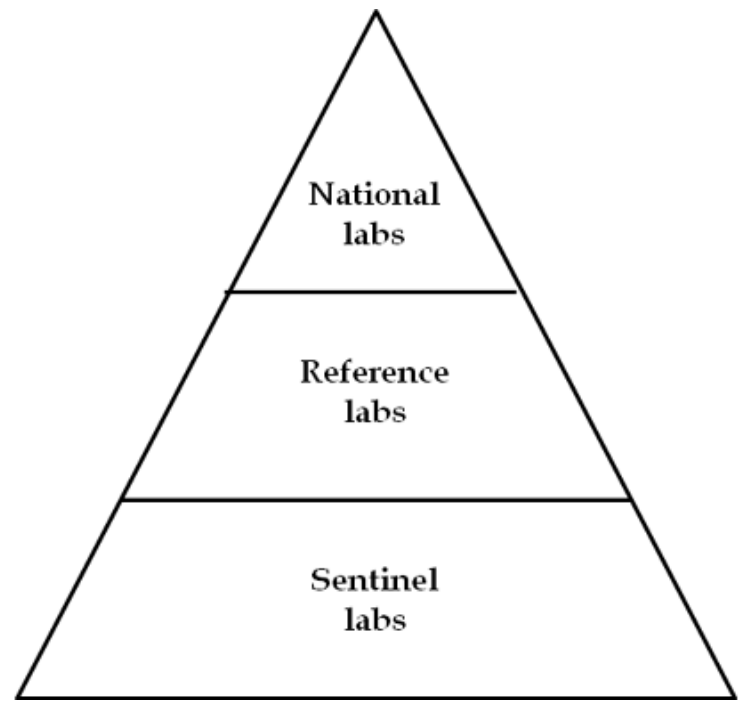

Fig. 1. The US Laboratory Response Networks in terms of operational components; National laboratories to perform definitive characterization, Reference laboratories to perform confirmatory testing and Sentinel labs to recognize and rule-out (Nauschuetz, 2005).

Instruments/equipments. The laboratories must be equipped with appropriate and evaluated instruments that also are operational in a BSL-3 or BSL-4 laboratory. The interior of these labs must also be designed for different chemical and gas decontamination methods. Many BSL-3 and BSL-4 laboratories are composed of stainless steel to allow decontamination work of highly pathogenic microorganisms, which require the highest level of cleanliness and durability. Proper biosafety cabinets, autoclaves, glove boxes and ventilation systems must continuously be monitored and tested. A lot of work in these 
laboratories is based on traditional methods such as labor intensive cultivation, autopsy and necropsy. However, there is a need to have alternative methods for complementary tests such as molecular based instruments in a BSL-3 level or BSL-4 environment. It is therefore important to evaluate computers, DNA extraction robots and PCR equipment from an operational point of view for these laboratories.

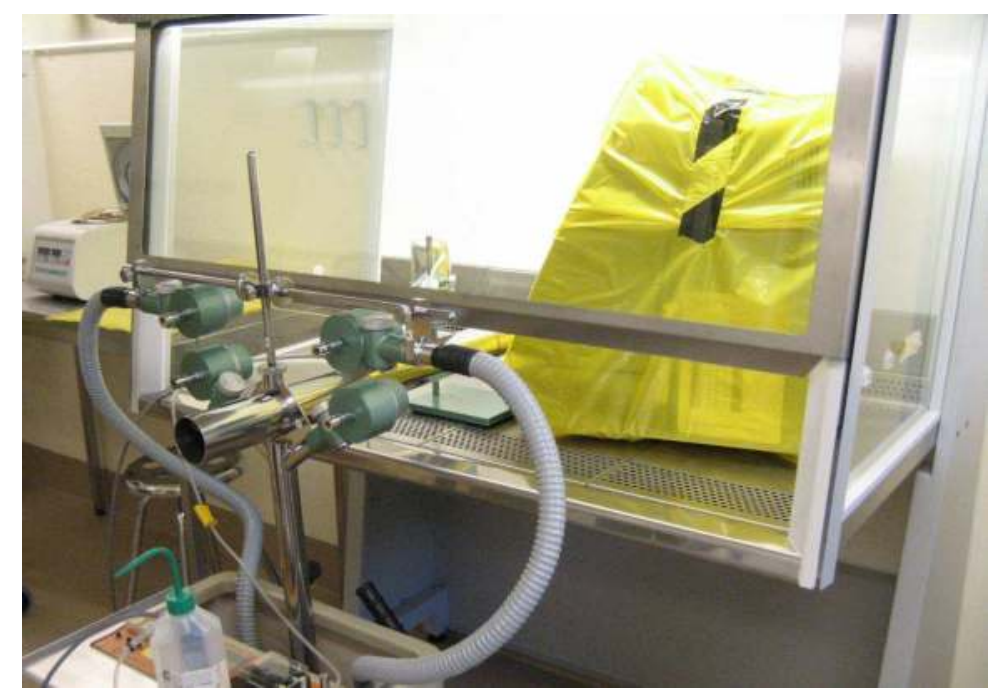

Fig. 2. The unique potassium iodide KI-discus-test, to validate a class II safety cabinet with a DNA isolation robot in a BSL-3 laboratory. The KI discus test is defined in the European Standard for microbiological safety cabinets, EN12469:2000 as a test method for validating the operator protection capabilities of the cabinet (Photo: SVA).

Staff. Having trained personnel is critical for the overall bioterrorism preparedness effort (Barden, 2002) and leadership (Marshall et al., 2010). Additional training and education is necessary to work in BSL-3 and BSL-4 labs. Minimum requirements in terms of general biosafety training include definitions of biological and bio-hazardous materials, risk groups, biosafety containment levels, controls and protective clothing including staff at sentinel laboratories (Wagar et al., 2010). Various training courses are available and one example is a Bioterrorism Preparedness Training for LRN Sentinel Laboratories offered by the National Laboratory Training Network (NLTN, 2011). It is important to have training on various diagnostic methods as well as training related to biosafety and biosecurity (Kalish et al., 2009). Joint laboratory exercises are used to evaluate the laboratory organization. Education is also crucial in the other sectors such as veterinary laboratories (Lowenstine et al., 2006).

\section{Laboratory standards, certification and methods}

Many regulations, practices, programs and inspections have to be met and/or fulfilled to be allowed to work on biothreat agents. This requires inspections at organizational-, facility- and personnel level. The regulations and inspections differ from country to country and from sector to sector. The US Select Agents Program clearly regulates the use 
and transfer of specific biological agents and the program promotes laboratory safety and security (CDC, 2010). Other countries such as the United Kingdom, France, Denmark, Japan, Australia and Canada also have programs for governing facilities and personnel working on biothreat agents (NCBI, 2009). The Biological Weapon Convention (BTWC) (UN, 1972) and the United Nations Security Council (UNSCR1540, 2004) states that each nation should take action to implement national measures to avoid misuse of biological agents. However, other groups also exist. One example is the Australian Group, which is an informal forum of countries which seeks to ensure that exports do not contribute to the development of biological weapons (AG, 2010). These various programs and conventions to avoid misuse of biological agents shall be considered for laboratories working on biothreat agents.

Laboratory standards. In 2004 the World Health Organization (WHO) published the latest edition of their biosafety manual (WHO, 2004). After publication of this manual, WHO continued to work and in 2006 they published the Biorisk Management: Laboratory Biosecurity Guidance (WHO, 2006). This guide integrates biosafety and biosecurity. The European Committee for Standardization/Comité Européen de Normalisation (CEN) has continued to work on the WHO Biorisk management standard, and in 2008 CEN published Laboratory Biorisk Management Standard CWA 15793:2008 (CEN, 2008). The biorisk management standard provides guidance to an organization to identify, monitor and control laboratory biosafety and biosecurity in order to ensure that organizations are well prepared to respond if biological agents are released or go missing.

Laboratory certification. For laboratories working on biothreat, BSL-3 and BSL-4 agents, it is important to have a certified laboratory to confirm that the organization and facility is working with the highest and most appropriate standards. For this reason the organization must operate within international guidelines and national regulations. Facilities working on biothreat agents require laboratory or personnel certification (Gottron, 2011). The laboratory certification process of BSL3- and BSL-4 laboratories involves compliance with a number of criteria in terms of bisafety and biosecurity. For instance, it includes a systematic review of safety processes within the laboratory such as personal protective equipment, building and system integrity and standard operating procedures (SOPs). It also includes administrative documentation and record retention systems. Therefore, to respond to a bioterrorism incident a laboratory certification process will form the basis for a well prepared and appropriate laboratory capability.

Laboratory methods and harmonized protocols. Harmonized methods and protocols are extremely important for multisectoral cooperation (Hodges et al., 2010). This means that standard protocols and reagents must be used to confirm tests. These activities can differ from country to country. To allow development of standardized and validated methods for detection and identification of biothreat agents, proficiency testing and ring trials by sending samples to different laboratories are required. For this reason a Critical Reagents Program (CRP) has been established in the US. The CRP collection includes inactivated antigens of select agent, genomic materials from biothreat agents and monoclonal and polyclonal antibodies of biothreat agents (CRP, 2011). This is a key component of laboratory preparedness as shortages of critical reagents will significantly influence the response testing (APHL, 2006). Based on validated reagents new methods can be developed, evaluated and tested (Donoso Mantke et al., 2005). The LRN laboratories use standardized protocols and reagents to detect and identify biothreat agents. The standardized protocols 
are developed in such a manner that they contain information for chain-of-custody requirements.

\section{Development of diagnostic response strategies}

Law enforcement and public health must plan together to develop diagnostic response strategies for overt and covert bioterrorism incidents. This involves joint efforts to: (i) follow-up on lessons learned from previous incidents; (ii) scenario planning, training and exercises; (iii) R\&D activities; and (iv) validate and implement methods in response plans. Methods for detection and identification of microorganisms and toxins forms the basis (Skinner et al., 2009) (Musshoff et al., 2009).

Lessons learned from bioterrorism incidents and biocrimes. Several bioterrorism incidents and biocrimes have taken place, which have provided important lessons learned. For example, some more well known cases includes a salmonellosis outbreak in Oregon, a shigellosis outbreak in Dallas, the anthrax attacks of 2001 (amerithrax) and the the Aum Shinrikyo's attempt to develop biological weapons. The first case, the source of the 1984

\begin{tabular}{|c|c|c|c|c|c|}
\hline Attackers & Motive & $\begin{array}{l}\text { Year and } \\
\text { location }\end{array}$ & Agent & $\begin{array}{l}\text { Distribution } \\
\text { and } \\
\text { transmission } \\
\text { mode }\end{array}$ & Reference \\
\hline $\begin{array}{l}\text { Rajneeshee } \\
\text { cult }\end{array}$ & $\begin{array}{l}\text { Religious motive to } \\
\text { gain political } \\
\text { control by } \\
\text { influencing an } \\
\text { election by making } \\
\text { voters ill. }\end{array}$ & $\begin{array}{l}\text { 1984, The } \\
\text { Dalles, } \\
\text { Oregon, USA }\end{array}$ & $\begin{array}{l}\text { Salmonella } \\
\text { typhimurium } \\
\text { ATCC } 14028\end{array}$ & $\begin{array}{l}\text { Sallad } \\
\text { bars/restaurants } \\
\text { (blue cheese } \\
\text { dressing, potato } \\
\text { salad, lettuce) }\end{array}$ & $\begin{array}{l}\text { (Torok et } \\
\text { al., 1997) }\end{array}$ \\
\hline $\begin{array}{l}\text { Aum } \\
\text { Shinrikyo }\end{array}$ & $\begin{array}{l}\text { An apocalyptic cult } \\
\text { with a motive to } \\
\text { trigger a world war }\end{array}$ & $\begin{array}{l}\text { 1993, Tokyo, } \\
\text { Japan }\end{array}$ & $\begin{array}{l}\text { Bacillus } \\
\text { anthracis }\end{array}$ & $\begin{array}{l}\text { Aerozolization } \\
\text { of a liquid } \\
\text { suspension of } B . \\
\text { anthracis }\end{array}$ & $\begin{array}{l}\text { Keim et } \\
\text { al., 2001; } \\
\text { Takahashi } \\
\text { et al., } \\
\text { 2004) } \\
\text { (Olson, } \\
\text { 1999) }\end{array}$ \\
\hline Lone wolf & $\begin{array}{l}\text { A laboratory } \\
\text { employee invited } \\
\text { other laboratory } \\
\text { workers to eat } \\
\text { pastries in the } \\
\text { coffee room }\end{array}$ & $\begin{array}{l}\text { 1996, at a } \\
\text { clinical } \\
\text { laboratory in } \\
\text { Dallas, Texas, } \\
\text { USA }\end{array}$ & $\begin{array}{l}\text { Shigella } \\
\text { dysenteriae } \\
\text { Type } 2\end{array}$ & $\begin{array}{l}\text { Contamination } \\
\text { of doughnuts } \\
\text { and muffins }\end{array}$ & $\begin{array}{l}\text { (Kolavic } \\
\text { et al., } \\
1997)\end{array}$ \\
\hline Lone wolf & $\begin{array}{l}\text { Increase the } \\
\text { importance of his } \\
\text { research }\end{array}$ & $\begin{array}{l}\text { 2001, USA } \\
\text { ("Amerithrax") }\end{array}$ & $\begin{array}{l}\text { Bacillus } \\
\text { anthracis }\end{array}$ & $\begin{array}{l}\text { Letters with } \\
\text { powder }\end{array}$ & $\begin{array}{l}\text { (FBI, } \\
\text { 2006) } \\
\text { (Butler et } \\
\text { al., 2002) }\end{array}$ \\
\hline
\end{tabular}

Table 1. Overview of some bioterrorism incidents/biocrimes (Dembek, 2007). 
salmonellosis outbreak in The Dalles, Oregon, was puzzling beacuse the epidemiological investigation revealed multiple items of food were involved instead of a single suspect item (Table 1). In total, 751 salmonellosis cases were identified and 45 persons were hospitalized.

This was a deliberate outbreak perpetrated by members of the Rajneeshee cult. The cult legally obtained Salmonella Typhimurium ATCC 14028 and spread cultures of this organism on salad bars in area restaurants. The cause of the outbreak was found to be due to intentional contamination in October 1985, when the Federal Bureau of Investigation (FBI) investigated the cult (McDade et al., 1998). The FBI together with an Oregon public health laboratory official found an open vial of the strain in their laboratory more than a year after the outbreak took place. The culture of Salmonella Typhimurium ATCC 14028 found at the Rajneeshees farm was identical and indistinguishable from the outbreak strain that was isolated from clinical specimens and food items. The retrospective epidemiology was consistent and the deliberate contamination of the salad bars was confirmed (Torok et al., 1997). The case demonstrated the need for having joint cooperation between law enforcement and public health investigations. In addition, the case showed that many different food items and matrices may be responsible for a deliberate foodborne outbreak challenging the diagnostic capabilities. Various sample preparations methods for the different food items and food matrices will be needed.

In 1993 the Japanese Aum Shinrikyo cult released aerosolized spores of B. anthracis on two occasions. The first event took place in June when the cult sprayed B. anthracis from the roof of a building in downtown Tokyo. A month later the cult sprayed B. anthracis from a moving truck onto and around the Imperial Place and the Japan's parliament building in Tokyo (Dembek, 2007). However, none of the attacks led to any anthrax cases. In 2001, samples collected from the exterior of the exposed buildings in Tokyo were analyzed and it was found that the B. anthracis isolates were similar to the Sterne 34F2 strain, which is the strain used in animal vaccines for anthrax and is regarded as nonpathogenic for immunocompetent individuals. The release of this strain had little possibility of causing harm or death (Takahashi et al., 2004). From this incident one can learn that environmental sampling and proper storage is important. It also showed that microbial forensics is important as it enabled the investigators to identify the strain of $B$. anthracis released 8 years after the incident (Keim et al., 2001).

During the period between October 29th and November 1, 1996, 13 workers at a clinical laboratory in Dallas, Texas developed acute and severe diarrhea after consumption of muffins or doughnuts (Carus, 2001). The pathogen Shigella dysenteriae type 2 was isolated from stool samples from the infected workers. This pathogen is uncommon and no other shigellosis outbreaks occurred in the US at that time. Furthermore, no work on Shigella had taken place at that clinical laboratory. However, an examination of the freezer in the clinical laboratory showed some evidence of tampering with reference cultures of $S$. dysenteriae type 2. In August 1997, a laboratory technician was convicted of deliberately infecting coworkers with Shigella dysenteriae type 2 and sentenced to 20 years in prison (Everett, 2002). The laboratory and epidemiological investigations revealed a match of the laboratory strain to those isolated from food and clinical specimens. The tracing and epidemiological study was helped by the fact that only postproduction adulteration of the baked muffins and doughnuts could have resulted in their successful contamination.

On October 4, 2001, shortly after 9/11, an inhalation anthrax case was reported in a 63-old male in Florida (Fennelly et al., 2004). Subsequently, additional persons were identified who 
were infected with B. anthracis. Before the end of 2001, 22 cases of anthrax and 5 deaths had been reported. All of the anthrax cases were among postal workers or persons who had been in contact with contaminated mail. Exceptional collaboration was required from the different agencies involved. This event emphasized the importance of conducting public health and criminal investigations at the same time. The LRN served as a resource for identifying the agent in both environmental and clinical samples. An important lesson learned from this outbreak is that fine particles of a biological agent can become airborne, thus contaminating areas and placing persons at a risk and the need of microbial forensic (Dance, 2006).

There are many lessons to be learned from these incidents. Different types of attackers such as extremist groups and lone wolves have been involved. In addition, these incidents necessitate that forensic and epidemiological investigations occur at the same time. For example, to provide the link between isolates from clinical and various environmental and food samples with the person responsible for the deliberate spread. The need for multiple response teams has also been identified as a lesson learned.

Preparedness scenarios, training and exercises: The use of planning and preparedness scenarios between public health and law enforcement organizations will contribute to developing diagnostic response strategies. Different software tools are available for different preparedness applications. Over the last 10 years, various scenarios have been developed and used for different purposes. Modeling and bioterrorism scenarios have been used to evaluate responses to attacks with different agents causing diseases such as anthrax (Zaric et al., 2008), (Hupert et al., 2009), Foot and Mouth Disease (Schoenbaum et al., 2003), and Qfever (Pappas et al., 2007), as well as decision making (O'Toole et al., 2001) and Bayesian approaches for estimating bioterror attacks (Ray et al., 2011). Different scenarios and exercises have been used to improve various counter measures such as a local bioterrorism exercise (Hoffman et al., 2000), an exercise on threat assessment and quantitative risk assessment (Zilinskas et al., 2004), and an exercise training bioterrorism surveillance system (Berndt, 2003). Because there are a number of published models and scenarios available these can be used to develop and improve scenarios to challenge diagnostic response strategies in terms of coordination, capabilities and capacity. Results and output from these scenarios, training and exercises can be used to initiate new R\&D activities.

R\&D activities. Joint R\&D activities between first responders, forensic institutes and public health officials will contribute to developing appropriate methods. However this requires strategic planning and a laboratory infrastructure. Many R\&D activities are performed in a specific sector, such as public health, animal health, food safety and law enforcement. Over the last few years joint diagnostic methods have been developed to counter bioterrorism. However, a lot of research has been performed without questioning the different diagnostic end-users at local, regional or national level and lessons learned from incidents and exercises have not always been considered. R\&D activities have involved a broad spectra of methods such as electron microscopy (Goldsmith et al., 2009), new molecular methods (Casman, 2004), automated testing (Byrne et al., 2003) and screening (Emanuel et al., 2005), immunoassays for toxins (2008), microarray and multiplexing and nanotechnology methods (Menezes, 2011). Although technology has improved significantly since 2001 many diagnostic methods are still based on immunoassays, ELISA and PCR (Kellogg, 2010). First responders uses primarily field 
based immunoassays and portable PCR-assays for biothreat detection, and local and sentinel public health laboratories uses traditional culture and biochemical assays, ELISAs and molecular-based PCR methods for biothreat identification. A problem with conventional detection methods are the lack of positive controls since these methods are based on living organisms. Rapid detection methods have been well investigated (Canton, 2005) (Peruski et al., 2003). The most useful technology for identification of biothreat agents is real-time PCR. However, microarray and multiplex assays for detection of biothreat agents, such as Bacillus anthracis, Francisella tularensis and Yersinia pestis by using multiplex qPCR have recently improved (Janse et al., 2010).

Implementation in response plans. Once new diagnostic methods are developed, they need to be evaluated and validated. This is an important step and requires access to reagents for proficiency testing and ring trial evaluations. Methods need to be validated for use in real incidents. The methods must also full fill requirements for forensic applications, which adds another aspect, see Table 2.

\begin{tabular}{|l|l|l|l|l|}
\hline Sample & $\begin{array}{l}\text { Monitoring and } \\
\text { surveillance }\end{array}$ & $\begin{array}{l}\text { Alarm } \\
\text { (covert } \\
\text { and/overt) }\end{array}$ & $\begin{array}{l}\text { Laboratory } \\
\text { Response }\end{array}$ & Forensics \\
\hline Animal & $\begin{array}{l}\text { Animal Health } \\
\text { and Animal } \\
\text { surveillance }\end{array}$ & $\begin{array}{l}\text { Veterinarians/ } \\
\text { First responders }\end{array}$ & $\begin{array}{l}\text { Veterinary } \\
\text { laboratories }\end{array}$ & $\begin{array}{l}\text { Forensic } \\
\text { laboratories }\end{array}$ \\
\hline Drinking water & $\begin{array}{l}\text { Food and } \\
\text { Environmental } \\
\text { monitoring }\end{array}$ & $\begin{array}{l}\text { Food inspectors/ } \\
\text { First responders }\end{array}$ & $\begin{array}{l}\text { Water and food } \\
\text { laboratories }\end{array}$ & $\begin{array}{l}\text { Forensic } \\
\text { laboratories }\end{array}$ \\
\hline Environmental & $\begin{array}{l}\text { Environmental } \\
\text { monitoring }\end{array}$ & $\begin{array}{l}\text { Environmental } \\
\text { inspectors/ } \\
\text { First responders }\end{array}$ & $\begin{array}{l}\text { Environmental } \\
\text { laboratories }\end{array}$ & $\begin{array}{l}\text { Forensic } \\
\text { laboratories }\end{array}$ \\
\hline Feed & $\begin{array}{l}\text { Agricultural, } \\
\text { Food and Animal } \\
\text { Health }\end{array}$ & $\begin{array}{l}\text { Agricultural } \\
\text { inspectors/ } \\
\text { First responders }\end{array}$ & $\begin{array}{l}\text { Agricultural and } \\
\text { veterinary } \\
\text { Laboratories }\end{array}$ & $\begin{array}{l}\text { Forensic } \\
\text { laboratories }\end{array}$ \\
\hline Food & Food surveillance & $\begin{array}{l}\text { Food inspectors/ } \\
\text { First responders }\end{array}$ & Food laboratories & $\begin{array}{l}\text { Forensic } \\
\text { laboratories }\end{array}$ \\
\hline Human clinical & $\begin{array}{l}\text { Human } \\
\text { syndromic } \\
\text { surveillance }\end{array}$ & $\begin{array}{l}\text { Physicians/ } \\
\text { First responders }\end{array}$ & $\begin{array}{l}\text { Clinical } \\
\text { laboratories } \\
\text { local, regional, } \\
\text { national) }\end{array}$ & $\begin{array}{l}\text { Forensic } \\
\text { laboratories }\end{array}$ \\
\hline Plant & Plant surveillance & Plant inspectors & $\begin{array}{l}\text { Agricultural } \\
\text { laboratories }\end{array}$ & $\begin{array}{l}\text { Forensic } \\
\text { laboratories }\end{array}$ \\
\hline
\end{tabular}

Table 2. A Bioterrorism response matrix outlining laboratory support and the multidisciplinary cooperation.

\section{Challenges - coordination, capability and capacity}

Diagnostic bioterrorism response strategies shall consider coordination/resilience, harmonization, robustness and high- resolution diagnostic tools. This includes R\&D efforts 
of multidisciplinary detection technologies related to sampling, sample preparation, biomarker discovery, multiplexing and high resolution diagnostic typing tools (Knutsson et al., 2011). Clear mandate for coordination of response mechanisms is crucial and strong links between early warning systems provide a basis for the diagnostic bioterrorism response strategies.

Coordination - public health and forensic laboratories. Full international cooperation and efficient detection technologies are essential in order to respond efficiently to a bioterrorism event. Considering the detection needs for covert and overt bioterrorism events will require a broad range of analytical tools. There are many promising technologies on the market but still there is a need to develop emerging technologies for different end-users. This can be promoted by multidisciplinary cooperation between first responders, forensic institutes and diagnostic laboratories representing LRNs. First responders have prerequisites to use the technology for a rapid identification of the agent on site and at the crime scene. The detection technology must be user friendly and allow usage in hot, warm and cold emergency zones. Forensic institutes' major interest is to maintain chain of custody and have methods that are validated for use in court, including methods for evaluation of the results given the circumstances of the case (forensic interpretation). Public and animal health diagnostic laboratories have in general other needs. They must have a broad range of diagnostic methods available for further characterization and typing of the etiological agent. In general, joint response teams and the coordination and back-up of different laboratories are therefore crucial. The decision making procedure is very important and it has been described that in response to bioterrorism clinicians must make decisions in 4 critical domains (diagnosis, management, prevention and reporting to public health) and public health organizations must make decisions in 4 other domains (interpretation of bioterrorism surveillance data, outbreak investigation, outbreak control and communication) (Bravata et al., 2004). Early warning and coordinated rapid detection is a backbone and therefore the physicians' ability to recognize potential cases in the identification and treatment of diseases associated with bioterrorism is crucial (Bush et al, 2001), as well as for veterinarians (Davis, 2004). Bioterrorism response clinicians are essential partners to LRNs (Gerberding et al., 2002) and especially at sentinel laboratories (Pien et al., 2006). Examples of the importance of the clinicians work is clearly documented (Maillard et al., 2002) (Harris et al., 2011) and also the consequences if the diseases is not identified (Harris et al., 2011).

Capability and harmonization. To announce, for instance an anthrax outbreak (Sternberg Lewerin et al., 2010), and to make a declaration of an incident, decision makers needs validated methods. Standardized and validated PCR assays for high risk agents, such as $B$. anthracis (Wielinga et al., 2011) (Scarlata et al., 2010) and C. botulinum neurotoxin (Fenicia et al., 2011) are fundamental for confirming disease outbreaks. The methods should be tested in different countries and in different types of laboratories.

Capacity and robustness. Initial sampling and rapid detection is crucial (Leport et al., 2011). However, feed, food, environmental and clinical samples all contains components that may inhibit the analysis (e.g., PCR-inhibitors). Appropriate sampling (Knutsson et al., 2003) and pre PCR processing strategies are therefore needed in order to circumvent inhibition. For this purpose models to investigate PCR inhibition is an important step to study and evaluate prior to applying a method for a specific purpose (Knutsson et al., 2002) (Knutsson et al, 2002). Another important function is to have a laboratory surge capability in different areas in order to improve the robustness of the diagnostic capacity during a bioterrorism incident. 


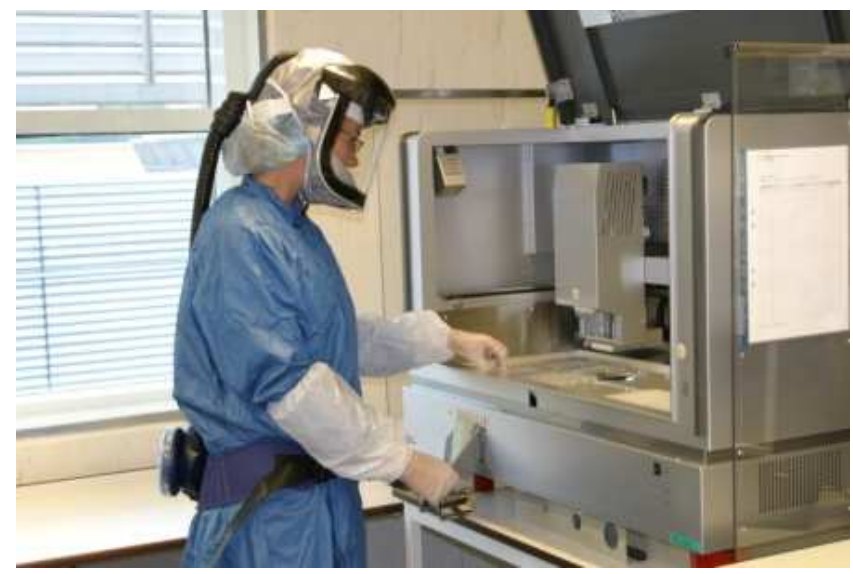

Fig. 3. Up-scaling capabilities by the use of automated DNA extractions robot in a BSL-3 laboratory (Photo: SVA).

High-resolution diagnostic tools. Multiplexing strategies for detection of several biomarkers (Lindberg et al., 2010), as well as various molecular typing methods are useful for crime scene investigation, but also for tracing and tracking the deliberate contamination. The use of massive parallel sequencing will be useful to study strain isolates from a suspicious deliberate contamination event. By applying bioinformatics it is possible to rapidly analyze large amounts of sequence data with minimal post-processing time (Segerman et al., 2011).

\section{Conclusions}

To obtain diagnostic bioterrorism response strategies a number of issues must be solved including strategic planning, laboratory infrastructure and standards. The laboratory work has to be strongly linked to different early warning and surveillance systems. Multiple teams as well as joint laboratory protocols are also important resources to have in place. The development of diagnostic bioterrorism response strategies should be based on lessons learned from previous attacks/incidents, planning scenarios, $R \& D$ activities and validation and implementations of methods. Laboratories must be able to detect, identify, respond and recover from covert and overt bioterrorism incidents. Key recommendations include:

- Multisectoral and international laboratory cooperation to obtain rapid detection and identification of biothreat agents

- Robust sampling and laboratory capacity for high-throughput needs

- Laboratory capabilities for diagnostic characterization needs

- Efficient IT-systems for sharing of data

\section{Acknowledgements}

Writing of this chapter has been supported by grants from the Swedish Civil Contingencies Agency (Anslag 2:4 Krisberedskap), Sweden (Swedish Laboratory Response Network), and the framework of the EU-project AniBioThreat (Grant Agreement: 
Home/2009/ISEC/AG/191) with the financial support from the Prevention of and Fight against Crime Programme of the European Union, European Commission - Directorate General Home Affairs. This publication reflects the views of the author, and the European Commission cannot be held responsible for any use which may be made of the information contained therein. A special thanks to Communication Officer Jeffrey Skiby (DTU-Food, Denmark) for critical reading and suggestion and to Professor Birgitta Rasmusson (the Swedish National Laboratory of Forensic Science, SKL) for critical reading with a focus on forensics and Dr Gary Barker (Institute of Food Research, IFR, United Kingdom) for valuable comments on the section of diagnostic response strategies.

\section{References}

AG. (2010). "The Australia Group - List of Biological Agents for Export Control."

APHL (2006). Critical Shortage of LRN Reagents. Silver Spring MD, Association of Public Health Laboratories (APHL)

Barden, L. S., Delany, J.R., Glenn, S., Perry, S.R., Lipman, H., Escott, S.H., Luck, L. (2002). Training Laboratory Personnel To Identify the Agents of Bioterrorism, Laboratory Medicine Vol.(9): 699-703.

Berndt, D. J., Fisher, J., W, Hevner, A.R., Studnicki, J (2003). Bioterrorism Surveillance with Real-Time Data Warehousing, Organization: IEEE Com Vol.

Brandeau, M. L., McCoy, J. H., Hupert, N., Holty, J. E. \& Bravata, D. M. (2009). Recommendations for modeling disaster responses in public health and medicine: a position paper of the society for medical decision making, Med Decis Making Vol.(4): 438-460.

Bravata, D. M., Sundaram, V., McDonald, K. M., Smith, W. M., Szeto, H., Schleinitz, M. D. \& Owens, D. K. (2004). Evaluating detection and diagnostic decision support systems for bioterrorism response, Emerg Infect Dis Vol.(1): 100-108.

Bush, L. M., Abrams, B. H., Beall, A. \& Johnson, C. C. (2001). Index case of fatal inhalational anthrax due to bioterrorism in the United States, N Engl J Med Vol.(22): 1607-1610.

Butler, J. C., Cohen, M. L., Friedman, C. R., Scripp, R. M. \& Watz, C. G. (2002). Collaboration between public health and law enforcement: new paradigms and partnerships for bioterrorism planning and response, Emerg Infect Dis Vol.(10): 1152-1156.

Byrne, K. M., Fruchey, I. R., Bailey, A. M. \& Emanuel, P. A. (2003). Automated biological agent testing systems, Expert review of molecular diagnostics Vol.(6): 759-768.

Canton, R. (2005). Role of the microbiology laboratory in infectious disease surveillance, alert and response, Clin Microbiol Infect Vol.: 3-8.

Carus, W. (2001). Working Paper: Bioterrorism and Biocrimes. The Illicit Use of Biological Agents Since 1900. F. Revision. Washington DC, Center for Counterproliferation Research, National Defense University.

Casman, E. A. (2004). The potential of next-generation microbiological diagnostics to improve bioterrorism detection speed, Risk Anal Vol.(3): 521-536.

CDC. (2007). "LRN Results Messenger and LIMS Integration."

CDC. (2010, http://www.bt.cdc.gov/agent/agentlist-category.asp). "CDC Bioterrorism Disease Agent List."

CEN (2008). The Laboratory Biorisk Management Standard.

CRP. (2011). "Critical Reagents Program (CRP)." 
CRTI (2007). Chemical, Biological, Radiological-Nuclear and Explosives Reserach and Technology Initiative. Canada, Canadian Reserach and Technology Initiative. Annual Report 2006-2007.

Dance, A. (2008) Anthrax case ignites new forensics field. Nature Vol.454, 813.

Davis, P. K., Bankes, S.C., Egner, M.F. (2007). Enhancing strategic planning with massive scenario generation: Theory and Experiments, Rand Corporation.

Davis, R. G. (2004). The AbCs of bioterrorism for veterinarians, focusing on Category B and C agents, J Am Vet Med Assoc Vol.(7): 1096-1104.

Dembek, Z., Pavlin, J., Kortepeter, M. (2007). Epidemiology of Biowarfare and Bioterrorism. Medical Aspects of Biological Warfare. J. Redding, Mason, V., Wise, D., Metzgar, M., Lindsay, R., Frazier, A. Washington DC, The Office of the Surgeon General at TMM Publications.

DHS (2005). NATIONAL PLANNING SCENARIOS: Executive Summaries. F. Created for Use in National, State, \&a. L. H. S. P. Activities. USA.

Donoso Mantke, O., Schmitz, H., Zeller, H., Heyman, P., Papa, A. \& Niedrig, M. (2005). Quality assurance for the diagnostics of viral diseases to enhance the emergency preparedness in Europe, Euro Surveill Vol.(6): 102-106.

EC (2009). Communication from the commission to the european parliament and the council on strengthening chemical, biological, radiological and nuclear security in the European Unioin - an EU CBRN Action Plan. C. o. t. e. communities.

Editorial (2004). Australian Society for Infectious Diseases: Bioterrorism Response Advisory Group. Microbiology Australia. Melbourne, Australia, The Australian Society for Microbiology Inc. 25: 46.

Emanuel, P. A., Fruchey, I. R., Bailey, A. M., Dang, J. L., Niyogi, K., Roos, J. W., Cullin, D. \& Emanuel, D. C. (2005). Automated screening for biological weapons in homeland defense, Biosecurity and bioterrorism : biodefense strategy, practice, and science Vol.(1): 39-50.

FBI (2006). Federal Bureau of Investigation. Amerithrax Fact Sheet - September 2006, http://www.fbi.gov/about-us/history/famous-cases/anthraxamerithrax/amerithrax-fact-sheet

Fenicia, L., Fach, P., van Rotterdam, B. J., Anniballi, F., Segerman, B., Auricchio, B., Delibato, E., Hamidjaja, R. A., Wielinga, P. R., Woudstra, C., Agren, J., De Medici, D. \& Knutsson, R. (2011). Towards an international standard for detection and typing botulinum neurotoxin-producing Clostridia types A, B, E and F in food, feed and environmental samples: a European ring trial study to evaluate a real-time PCR assay, Int J Food Microbiol Vol.: S152-157.

Fennelly, K. P., Davidow, A. L., Miller, S. L., Connell, N. \& Ellner, J. J. (2004). Airborne infection with Bacillus anthracis--from mills to mail, Emerging infectious diseases Vol.(6): 996-1002.

Gerberding, J. L., Hughes, J. M. \& Koplan, J. P. (2002). Bioterrorism preparedness and response: clinicians and public health agencies as essential partners, JAMA Vol.(7): 898-900.

Goldsmith, C. S. \& Miller, S. E. (2009). Modern uses of electron microscopy for detection of viruses, Clin Microbiol Rev Vol.(4): 552-563.

Gottron, F., Shea, D.A., (2011). Federal Efforts to Address the Threat of Bioterrorism: Selected Issues and Options for Congress. C. R. Service, CRS Report for Congress. 
Gullino, M., L., Fletcher, J., Gamliel, A., Stack, J.P. (2008). Crop Biosecurity - Assuring our Global Food Supply. Dordrecht, Springer.

Harris, M. D. \& Yeskey, K. (2011). Bioterrorism and the vital role of family physicians, Am Fam Physician Vol.(1): 18, 20.

Hodges, L. R., Rose, L. J., O'Connell, H. \& Arduino, M. J. (2010). National validation study of a swab protocol for the recovery of Bacillus anthracis spores from surfaces, $J$ Microbiol Methods Vol.(2): 141-146.

Hoffman, R. E. \& Norton, J. E. (2000). Lessons learned from a full-scale bioterrorism exercise, Emerging infectious diseases Vol.(6): 652-653.

Holmdahl, L., Granelli, K., Lorentzon, P., Danielsson, C., Knutsson, R., Myrén, S. (2011). Identifiering av larmvägar i händelse av avsiktlig smittspridning, biokriminalitet och bioterrorism, Vol.

Horton, H. H., Misrahi, J. J., Matthews, G. W. \& Kocher, P. L. (2002). Critical biological agents: disease reporting as a tool for determining bioterrorism preparedness, J Law Med Ethics Vol.(2): 262-266.

Hupert, N., Mushlin, A. I. \& Callahan, M. A. (2002). Modeling the public health response to bioterrorism: using discrete event simulation to design antibiotic distribution centers, Med Decis Making Vol.(5 Suppl): S17-25.

Hupert, N., Wattson, D., Cuomo, J., Hollingsworth, E., Neukermans, K. \& Xiong, W. (2009). Predicting hospital surge after a large-scale anthrax attack: a model-based analysis of CDC's cities readiness initiative prophylaxis recommendations, Med Decis Making Vol.(4): 424-437.

Hwang, H. S. (2008). [The strategic plan for preparedness and response to bioterrorism in Korea], J Prev Med Public Health Vol.(4): 209-213.

INTERPOL (2010). Bioterrorism Incident Pre-Planning \& Response Guide. Lyon, France, INTERPOL.

Janse, I., Hamidjaja, R. A., Bok, J. M. \& van Rotterdam, B. J. (2010). Reliable detection of Bacillus anthracis, Francisella tularensis and Yersinia pestis by using multiplex qPCR including internal controls for nucleic acid extraction and amplification, BMC microbiology Vol.: 314.

Kalish, B. T., Gaydos, C. A., Hsieh, Y. H., Christensen, B. E., Carroll, K. C., Cannons, A., Cattani, J. A. \& Rothman, R. E. (2009). National survey of Laboratory Response Network sentinel laboratory preparedness, Disaster Med Public Health Prep Vol.(2 Suppl): S17-23.

Keim, P., Smith, K. L., Keys, C., Takahashi, H., Kurata, T. \& Kaufmann, A. (2001). Molecular investigation of the Aum Shinrikyo anthrax release in Kameido, Japan, J Clin Microbiol Vol.(12): 4566-4567.

Kellogg, M. (2010). Detection of biological agents used for terrorism: are we ready?, Clinical chemistry Vol.(1): 10-15.

Knutsson, R. (2011). A tracing tool portfolio to detect Bacillus anthracis, Clostridium botulinum and Noroviruses: bioterrorism is a food safety and security issue, Int J Food Microbiol Vol.: S121-122.

Knutsson, R., Lofstrom, C., Grage, H., Hoorfar, J. \& Radstrom, P. (2002). Modeling of 5' nuclease real-time responses for optimization of a high-throughput enrichment PCR procedure for Salmonella enterica, J Clin Microbiol Vol.(1): 52-60. 
Knutsson, R. \& Rådström, P. (2003). Detection of pathogenic Yersinia enterocolitica by a swab enrichment PCR procedure, Methods Mol Biol Vol.: 311-324.

Knutsson, R., van Rotterdam, B., Fach, P., De Medici, D., Fricker, M., Lofstrom, C., Agren, J., Segerman, B., Andersson, G., Wielinga, P., Fenicia, L., Skiby, J., Schultz, A. C. \& Ehling-Schulz, M. (2011). Accidental and deliberate microbiological contamination in the feed and food chains--how biotraceability may improve the response to bioterrorism, Int J Food Microbiol Vol.: S123-128.

Kolavic, S. A., Kimura, A., Simons, S. L., Slutsker, L., Barth, S. \& Haley, C. E. (1997). An outbreak of Shigella dysenteriae type 2 among laboratory workers due to intentional food contamination, JAMA Vol.(5): 396-398.

Koplan, J. (2001). CDC's strategic plan for bioterrorism preparedness and response, Public Health Rep Vol.: 9-16.

Kun, L. G. \& Bray, D. A. (2002). Information infrastructure tools for bioterrorism preparedness. Building dual- or multiple-use infrastructures is the task at hand for state and local health departments, IEEE Eng Med Biol Mag Vol.(5): 69-85.

Leport, C., Vittecoq, D., Perronne, C., Debord, T., Carli, P., Camphin, P. \& Bricaire, F. (2011). [Infections at risk for epidemic or biological threat. Importance of the initial management of suspect patients], Presse Med Vol.(4 Pt 1): 336-340.

Lindberg, A., Skarin, H., Knutsson, R., Blomqvist, G. \& Baverud, V. (2010). Real-time PCR for Clostridium botulinum type $\mathrm{C}$ neurotoxin (BoNTC) gene, also covering a chimeric C/D sequence--application on outbreaks of botulism in poultry, Vet Microbiol Vol.(1-2): 118-123.

Lowenstine, L. J. \& Montali, R. J. (2006). Historical perspective and future directions in training of veterinary pathologists with an emphasis on zoo and wildlife species, $J$ Vet Med Educ Vol.(3): 338-345.

Maillard, J. M., Fischer, M., McKee, K. T., Jr., Turner, L. F. \& Cline, J. S. (2002). First case of bioterrorism-related inhalational anthrax, Florida, 2001: North Carolina investigation, Emerg Infect Dis Vol.(10): 1035-1038.

Margolis, D. A., Burns, J., Reed, S. L., Ginsberg, M. M., O'Grady, T. C. \& Vinetz, J. M. (2008). Septicemic plague in a community hospital in California, Am J Trop Med Hyg Vol.(6): 868-871.

Marshall, S. A., Brokopp, C. D. \& Size, T. (2010). Leadership principles for developing a statewide public health and clinical laboratory system, Public Health Rep Vol.: 110117.

McDade, J. E. \& Franz, D. (1998). Bioterrorism as a public health threat, Emerg Infect Dis Vol.(3): 493-494.

Menezes, G. A., Menezes, P,S., Menezes, C. (2011). Nanoscience in diagnostics: A short review, Internet Journal of Medical Update 2011 January Vol.(1): 16-23.

Morse, S. A., Kellogg, R.B., Perry, S., Meyer, R.F., Bray, D., Nichelson, D., Miller, J.M. (2003). Detecting Biothreat Agents: the Laboratory Response Network, ASM News Vol.(9): 433-437.

Morse, S. A., Kellogg, R.B., Perry, S., Meyer, R.F., Bray, D., Nichelson, D., Miller, J.M. (2004). The Laboratory Response Network. Preparedness Against Bioterrorism and ReEmerging Infectious Diseases. J. Kocik, Janiak, M., Negut, M. Amsterdam, IOS Press: 26-35. 
Musshoff, F. \& Madea, B. (2009). Ricin poisoning and forensic toxicology, Drug Test Anal Vol.(4): 184-191.

Nauschuetz, W. F. (2005). Straight talk on bioterror from the Army's LRN gatekeeper, MLO Med Lab Obs Vol.(6): 10-11, 14, 16; quiz 18-19.

NCBI (2009). National Research Council (US) Committee on Laboratory Security and Personnel Reliability Assurance Systems for Laboratories Conducting Research on Biological Select Agents and Toxins. Responsible Research with Biological Select Agents and Toxins. Washington DC, National Academies Press

NLTN (2011). Bioterrorism Preparedness Training for Sentinel Laboratories 2011, National Laboratory Training Network: www.nltn.org/305-311.htm.

O'Toole, T. \& Inglesby, T. V. (2001). Epidemic response scenario: decision making in a time of plague, Public health reports Vol.: 92-103.

Olson, K. B. (1999). Aum Shinrikyo: once and future threat?, Emerg Infect Dis Vol.(4): 513516.

Pappas, G., Blanco, J. R. \& Oteo, J. A. (2007). Q fever in Logrono: an attack scenario, Enferm Infecc Microbiol Clin Vol.(3): 199-203.

Pearson, G. S. (2006). Public perception and risk communication in regard to bioterrorism against animals and plants, Rev Sci Tech Vol.(1): 71-82.

Peruski, L. F., Jr. \& Peruski, A. H. (2003). Rapid diagnostic assays in the genomic biology era: detection and identification of infectious disease and biological weapon agents, Biotechniques Vol.(4): 840-846.

Pien, B. C., Saah, J. R., Miller, S. E. \& Woods, C. W. (2006). Use of sentinel laboratories by clinicians to evaluate potential bioterrorism and emerging infections, Clin Infect Dis Vol.(9): 1311-1324.

Ray, J., Marzouk, Y. M. \& Najm, H. N. (2011). A Bayesian approach for estimating bioterror attacks from patient data, Stat Med Vol.(2): 101-126.

Rotz, L. D. \& Hughes, J. M. (2004). Advances in detecting and responding to threats from bioterrorism and emerging infectious disease, Nat Med Vol.(12 Suppl): S130-136.

Scarlata, F., Colletti, P., Bonura, S., Trizzino, M., Giordano, S. \& Titone, L. (2010). [The return of anthrax. From bioterrorism to the zoonotic cluster of Sciacca district], Infez Med Vol.(2): 86-90.

Schoenbaum, M. A. \& Terry Disney, W. (2003). Modeling alternative mitigation strategies for a hypothetical outbreak of foot-and-mouth disease in the United States, Prev Vet Med Vol.(1-2): 25-52.

Segerman, B., De Medici, D., Ehling Schulz, M., Fach, P., Fenicia, L., Fricker, M., Wielinga, P., Van Rotterdam, B. \& Knutsson, R. (2011). Bioinformatic tools for using whole genome sequencing as a rapid high resolution diagnostic typing tool when tracing bioterror organisms in the food and feed chain, Int J Food Microbiol Vol.: S167-176.

Sintchenko, V. \& Gallego, B. (2009). Laboratory-guided detection of disease outbreaks: three generations of surveillance systems, Arch Pathol Lab Med Vol.(6): 916-925.

Skinner, C., Thomas, J., Johnson, R. \& Kobelski, R. (2009). Medical toxicology and public health--update on research and activities at the Centers for Disease Control and Prevention, and the Agency for Toxic Substances and Disease Registry: introduction to the Laboratory Response Network-Chemical (LRN-C), J Med Toxicol Vol.(1): 46-49. 
Smith, L. A. (2004). Bioterrorism: what level is the threat and are vaccines the answer?, Expert Rev Vaccines Vol.(5): 493-495.

Sternberg Lewerin, S., Elvander, M., Westermark, T., Nisu Hartzell, L., Karlsson-Norstrom, A., Ehrs, S., Knutsson, R., Englund, S., Andersson, A. C., Granberg, M., Backman, S., Wikstrom, P. \& Sandstedt, K. (2010). Anthrax outbreak in a Swedish beef cattle herd - 1st case in 27 years: Case report, Acta Veterinaria Scandinavica Vol.(1): 7.

Sundelius, B. \& Gronvall, J. (2004). Strategic dilemmas of biosecurity in the European Union, Biosecur Bioterror Vol.(1): 17-23.

Takahashi, H., Keim, P., Kaufmann, A. F., Keys, C., Smith, K. L., Taniguchi, K., Inouye, S. \& Kurata, T. (2004). Bacillus anthracis incident, Kameido, Tokyo, 1993, Emerg Infect Dis Vol.(1): 117-120.

Tegnell, A., Bossi, P., Baka, A., Van Loock, F., Hendriks, J., Wallyn, S. \& Gouvras, G. (2003). The European Commission's Task Force on Bioterrorism, Emerg Infect Dis Vol.(10): 1330-1332.

Torok, T. J., Tauxe, R. V., Wise, R. P., Livengood, J. R., Sokolow, R., Mauvais, S., Birkness, K. A., Skeels, M. R., Horan, J. M. \& Foster, L. R. (1997). A large community outbreak of salmonellosis caused by intentional contamination of restaurant salad bars, JAMA Vol.(5): 389-395.

UN (1972). Convention of the Prohibition of the Development, Production and Stockpiling of Bacteriological (Biological) and Toxins Weapons and on thier Destruction. U. Nations. London, Moscow, Washington. Entered into force 26 March 1976.

UNSCR1540 (2004). United Nations Security Council Resolution 1540, United Nations.

Wagar, E. A., Mitchell, M. J., Carroll, K. C., Beavis, K. G., Petti, C. A., Schlaberg, R. \& Yasin, B. (2010). A review of sentinel laboratory performance: identification and notification of bioterrorism agents, Arch Pathol Lab Med Vol.(10): 1490-1503.

WHO (2004). Laboratory Biosafety Manual. Geneva, World Health Organisation. 3rd.

WHO (2006). Biorisk management - Laboratory biosecurity guidance. Geneva, World Health Organisation.

Wielinga, P. R., Hamidjaja, R. A., Agren, J., Knutsson, R., Segerman, B., Fricker, M., EhlingSchulz, M., de Groot, A., Burton, J., Brooks, T., Janse, I. \& van Rotterdam, B. (2011). A multiplex real-time PCR for identifying and differentiating B. anthracis virulent types, Int J Food Microbiol Vol.: S137-144.

Zarcone, P., Nordenberg, D., Meigs, M., Merrick, U., Jernigan, D. \& Hinrichs, S. H. (2010). Community-driven standards-based electronic laboratory data-sharing networks, Public Health Rep Vol.: 47-56.

Zaric, G. S., Bravata, D. M., Cleophas Holty, J. E., McDonald, K. M., Owens, D. K. \& Brandeau, M. L. (2008). Modeling the logistics of response to anthrax bioterrorism, Med Decis Making Vol.(3): 332-350.

Zilinskas, R. A., Hope, B. \& North, D. W. (2004). A discussion of findings and their possible implications from a workshop on bioterrorism threat assessment and risk management, Risk analysis: an official publication of the Society for Risk Analysis Vol.(4): 901-908. 


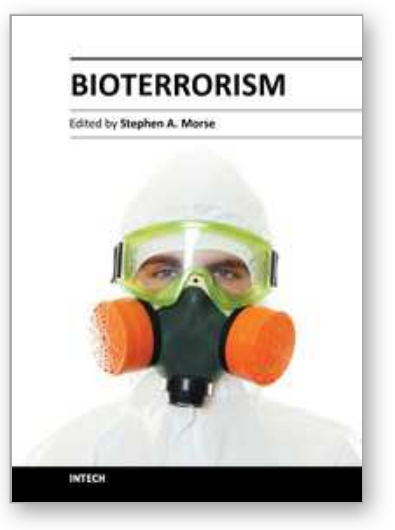

\author{
Bioterrorism \\ Edited by Dr. Stephen Morse
}

ISBN 978-953-51-0205-2

Hard cover, 192 pages

Publisher InTech

Published online 28, March, 2012

Published in print edition March, 2012

This book consists of nine chapters, written by international authorities, discussing various aspects of bioterrorism preparedness and response. Five of the chapters are agent-specific and highlight the pathogenesis, prevention and treatment, and the potential of specific organisms (Rickettsia and Yersinia pestis) or toxins (ricin, botulinum neurotoxins, and staphylococcal enterotoxins) to be used for nefarious purposes. Four chapters discuss different aspects of detecting and responding to a bioterrorism attack. These include methods for spatio-temporal disease surveillance, international laboratory response strategies, detection of botulinum neurotoxins in food and other matrices, and the use of physical methods (ie Raman spectroscopy) to detect spores.

\title{
How to reference
}

In order to correctly reference this scholarly work, feel free to copy and paste the following:

Rickard Knutsson (2012). Diagnostic Bioterrorism Response Strategies, Bioterrorism, Dr. Stephen Morse (Ed.), ISBN: 978-953-51-0205-2, InTech, Available from: http://www.intechopen.com/books/bioterrorism/diagnosticresponse-strategies

\section{INTECH}

open science | open minds

\section{InTech Europe}

University Campus STeP Ri Slavka Krautzeka 83/A 51000 Rijeka, Croatia Phone: +385 (51) 770447

Fax: +385 (51) 686166 www.intechopen.com

\section{InTech China}

Unit 405, Office Block, Hotel Equatorial Shanghai No.65, Yan An Road (West), Shanghai, 200040, China 中国上海市延安西路65号上海国际贵都大饭店办公楼 405 单元 Phone: +86-21-62489820

Fax: +86-21-62489821 
(C) 2012 The Author(s). Licensee IntechOpen. This is an open access article distributed under the terms of the Creative Commons Attribution 3.0 License, which permits unrestricted use, distribution, and reproduction in any medium, provided the original work is properly cited. 